\title{
President Trump Peace Strategy: Emerging Conflict Between Israel and Palestine
}

\author{
Jibrin Ubale Yahaya, $\mathrm{PhD}$ \\ Department of Political Science, National Open University of Nigeria (NOUN), Jabi Abuja
}

\begin{abstract}
When Donald Trump was elected as US President in November 2016, he initially signaled some real hope for the peaceful resolution of the Israeli-Palestinian conflict. Some analysts argued that he may actually manage to deliver what he calls "the deal of the century" and bring peace to Israel and Palestine. These assumptions were based on the fact that President Trump is the type of person that could wake up one morning, say "enough", and pressure Israeli and Palestinian leaders to sign a peace deal on his terms. Early on in his presidency, Trump made the conflict a strategic priority and unconventionally chose to go to the Middle East (Saudi Arabia, Israel and Palestine) on his first trip abroad as President. During a press conference with Palestinian Authority President Mahmoud Abbas in Bethlehem, he said that "if Israel and the Palestinians can make peace, it will begin a process of peace all throughout the Middle East." This was in line with Europe's standard inside-out approach (Israeli-Palestinian peace first, Israeli-Arab normalization later). But on December 2019, Trump made it clear that his much-anticipated peace deal will favour Israel when he recognized Jerusalem as Israel's capital and promised to move the US embassy there. This led Abbas to brand Trump's peace efforts as "the slap of the century" and say the US could no longer play any role in the Middle East peace process following the move. This paper has general objective of appraising the Trump peace deal in Middle East, and evaluate it to see does the process would bring real peace or escalation of crisis in the Middle East. The paper has argued that for peace to be guaranteed in the Middle East, justice, fair play and inclusiveness must be demonstrated by any third party who want intervene and bring peace in the Middle East.
\end{abstract}

Keywords: Conflict, Middle East, Peace Deal, US intervention

DOI: $10.7176 / \mathrm{IAGS} / 82-04$

Publication date:May $31^{\text {st }} 2020$

\section{Introduction}

President Trump seemed to be in favour of the outside-in approach (Israeli-Arab normalization first, IsraeliPalestinian peace later) to the conflict. Moreover, he regularly changed his position in the debate - he was for, against and in between on key final status issues such as the settlements and moving the US embassy to Jerusalem, while never taking a clear stand for or against a two-state solution (Kevin, 2018)

In November 2017, it was reported that Trump's peace plan would oversee the establishment of an independent Palestinian state in an unspecified territory, but without Jerusalem as its capital and with all the settlements remaining. The report, based on the testimonies of anonymous senior officials of Israel's negotiating team, also signaled that Trump's plan would ignore the Palestinians' right of return and give the control of the Jordan Valley to Israel. Around the same time, it was also reported that Abbas was summoned to Riyadh and told by Crown Prince Mohammed bin Salman to either accept Trump's peace plan or resign (Bill, 2019)

In the February 2018, it was reported that in Arab and Israeli media that Trump's peace plan would entail the relocation of some minor settlements, a possible Palestinian capital in East Jerusalem and some form of international protection for the Holy sites in Jerusalem - seemingly an upgrade for the Palestinians, even if it still fell far short of their demands. Moreover, the PA's intelligence chief, Majid Faraj, has seen the latest version of the 35-page peace plan in Riyadh. According to Palestinian officials that spoke to the media on condition of anonymity, this version of the peace plan included the establishment of a Palestinian state with provisional borders on half of the West Bank and the Gaza Strip, without Jerusalem, and with only humanitarian solutions to the refugee issue. The plan, moreover, calls for "building a new Jerusalem for the Palestinians from the city's surrounding villages" and also keeps Palestinian security and borders in the hands of Israel (Ghosh, 2019)

\section{Statement of Problem}

There seems to be consensus among the Palestinian leadership that Trump's plan, as it stands today, is something that "no Palestinian leader could accept". Abbas himself has said that the plan's objective is "to destroy the Palestinian national project".

Edward (2019) Said described the Oslo Accords as a "Palestinian surrender, a Palestinian Versailles" 25 years ago, so what should we call Trump's "deal of the century"? A mini-Palestine is perhaps the correct term, as it will only consist of Gaza and 50 percent of the West Bank - together amounting to no more than 11.5 percent of historic Palestine.

Nicky Haley, the US ambassador to the UN, said that "the plan won't be loved by either side", but so far there 
has been little, if any, critique in Israel against it. In fact, the plan seems to give Israel everything it wants. Trump's plan as it stands today should be seen as a combination of several earlier Israeli proposals: the 1967 Allon Plan (in which Israel sought to control the West Bank's outer borders, except for a small corridor, and keep valuable territories but not major Palestinian population centers), the 1977 Likud autonomy plan (which sought autonomy for the Palestinian population but not for the territory), and the 2009 Mofaz plan (which sought to establish a Palestinian state with temporary borders on 60 percent of the West Bank, that, according to Mofaz, would have included 99 percent of the West Bank's Palestinian population).

The latest round of leaks also implies that Trump's peace plan will go ahead with or without the Palestinian approval. This would mean a unilateral Israeli withdrawal from parts of the West Bank if the Palestinians reject the plan, as they are widely expected to do. A unilateral Israeli withdrawal from parts of the West Bank is precisely what the INSS, the leading centre-left Israeli think-tank, has long advocated for.

In this context, it is worth remembering that a similar discussion to this conflict took place nearly 15 years ago, when Israel decided to unilaterally disengage from Gaza. Back then, when Ariel Sharon presented his plan to unilaterally disengage from Gaza, because he did not want to negotiate an agreement with Abbas, whom he called a "plucked chicken", many analysts said the Palestinians and the international community would not accept the legitimacy of the unilateral disengagement plan. But they all did. Gaza immediately became a valued prize for the rival Palestinian factions, the EU provided monitors for the Rafah crossing in southern Gaza, and Sharon's image was transformed in many parts of the world from a war criminal to a celebrated statesman. Could something like this happen this time as well?

\section{Research Questions}

The paper has the following questions to ask:

i. $\quad$ What are basis of President Trump peace deal in Middle East?

ii. $\quad$ Does the President Trump peace deal can bring peace between Palestine and Israel

iii. What are the ways does peace be sustain between the Palestine and Israel

\section{Research Objectives}

The paper has the general objectives of the issues of long time conflict between the Palestine and Israel with the following specific objectives:

i. $\quad$ To find out the basis of President Trump peace deals in Middle East.

ii. To examine the President Trump peace deal effort between Palestine and Israel

iii. To investigate the ways on how peace can be sustain between the Palestine and Israel

\section{Research Methodology}

The paper has uses the secondary source of information through reviewing various literature on the contemporary issues of conflict between the Palestine and Israel and how the paper could suggest various alternatives strategies on how to end the crisis in Palestine and Israel .

\section{Definition of Concepts \\ Peace Plan Strategies goal}

The Trump peace plan is a blue print to "Israeli-Palestinian Peace Agreement" which will end the conflict between Israelis and Palestinians, and end all claims between the parties. (White House, 2020) The success is defined as finalized plan to be codified by UN Security Council resolution, and then a new UN General Assembly resolution replacing previous resolutions. The successful solutions give Palestinians all the power to govern themselves but not the powers to threaten Israel. (White House, 2020) The successful solution will direct flights between the State of Israel and its neighbors.

\section{Conditions for the Peace Deal Israeli conditions}

The plan requires no conditions of Israel in order for it to proceed with annexation. (Trump 2018) On 29 January, 2019 the US ambassador to Israel said that before any annexation of the West Bank or the Jordan Valley took place the Trump administration "wants to form a joint committee with Israel to discuss the issue." and that "it is impossible to know how long this process will take... we need to ensure the annexation matches the map in our plan."(Trump Peace Plan, 2019)

\section{Palestinian conditions}

In order for the Palestinians to benefit from any part of the plan, Israel and the United States asserted that the following conditions "must be determined to have occurred by the State of Israel and the United States, jointly".(Peace Plan, P.34) The PLO and the Palestinian Authority shall: (White House,p.43) Refrain from any 
attempt to join any international organization without the consent of the State of Israel; ( White House, P.43)

1. Take no action, and shall dismiss all pending actions, against the State of Israel, the United States and any of their citizens before the International Criminal Court, the International Court of Justice, and all other tribunals;

2. Take no action against any Israeli or United States citizen before Interpol or any non-Israeli or United States (as applicable) legal system;

3. Take all necessary actions to immediately terminate the paying of salaries to terrorists serving sentences in Israeli prisons, as well as to the families of deceased terrorists and to develop humanitarian and welfare programs to provide essential services and support to Palestinians in need that are not based upon the commission of terrorist acts. The goal is to change the applicable laws, in a manner that is consistent with the laws of the United States, and completely cease making Prisoner and Martyr Payments by the time of signing of the Israeli-Palestinian Peace Agreement; and further the development of institutions necessary for self-governance.

\section{Economy}

According to Janed, K (2019) has cited that the plan proposes a \$50 billion investment fund for 179 infrastructure and business projects, to be administered by a "multilateral development bank", with investments protected by "accountability, transparency, anti-corruption, and conditionality safeguards". The Reuters (2019) highlighted that the US administration envisions the plan being funded mostly by Arab states and wealthy private investors. Spending is divided into \$26 billion in loans, \$13.5 billion in grants, and \$11 billion in private investment (Eric, 2019)

The majority of the $\$ 50$ billion would be spent in the West Bank and Gaza, with $\$ 9$ billion to be spent in Egypt, $\$ 7$ billion in Jordan, and \$6.3 billion in Lebanon.(Jewish Telegraphic Agency,2019) The proposal includes a number of specific projects, including construction of a travel corridor that would cross Israel to link the West Bank and Gaza with a highway and possibly a rail line, vast expansion of border crossings, power plant upgrades, infrastructure improvements to boost tourism, career counseling and job placement service, re-building and modernizing Palestinian hospitals and health clinics, upgrading cargo terminals and building special access roads to reduce the time and costs of cross-border trade and travel, creating of a modern database to register land ownership, improving the potable water supply and waste water treatment, and establishing a new Palestinian university in the global top 150.( Reuters,2020)

The plan advocates a free market including greater protection of property rights and a "pro-growth tax structure." (Mahmians, 2019) The plan's stated goals include creating more than a million jobs, more than doubling the Palestinian GDP, and cutting the poverty rate by $50 \%$. It also aims to bring down the unemployment from $31 \%$ down to single digits, and to increase Palestinian exports as a percentage of GDP from $17 \%$ to $40 \%$. The plan also aims to increase female labor force participation rate from $20 \%$ to $35 \%$, reduce infant mortality from 18 to 9 per 1000 births, and increase average life expectancy from 74 to 80 years. (Reuters, 2020)

\section{Status of State of Palestine}

Trump plan declared "support" for an independent, sovereign State of Palestine with a capital on the outskirts of East Jerusalem. The plan would involve the creation of a Palestinian state with a capital in East Jerusalem, dependent on Palestinians taking steps to become self-governing. Trump plan is offering the Palestinians a state, a future State of Palestine, which will be not established up to four years into the execution of the plan.(White House,2020) The State of Palestine shall be fully demilitarized and remain as so( Trump Peace Plan,2018)

\section{Recognition Criteria}

The following criteria are a predicate to the formation of a Palestinian State and must be determined to have occurred by the State of Israel and the United States, jointly, acting in good faith, after consultation with the Palestinian Authority:

- The Palestinians shall have implemented a governing system with a constitution or another system for establishing the rule of law that provides for freedom of press, free and fair elections, respect for human rights for its citizens, protections for religious freedom and for religious minorities to observe their faith, uniform and fair enforcement of law and contractual rights, due process under law, and an independent judiciary with appropriate legal consequences and punishment established for violations of the law.

- The Palestinians shall have established transparent, independent, and credit-worthy financial institutions capable of engaging in international market transactions in the same manner as financial institutions of western democracies with appropriate governance to prevent corruption and ensure the proper use of such funds, and a legal system to protect investments and to address market-based commercial expectations. The State of Palestine should meet the independent 
objective criteria to join the International Monetary Fund.

- The Palestinians shall have ended all programs, including school curricula and textbooks, that serve to incite or promote hatred or antagonism towards its neighbors, or which compensate or incentivize criminal or violent activity.

- The Palestinians shall have achieved civilian and law enforcement control over all of its territory and demilitarized its population.

- The Palestinians shall have complied with all the other terms and conditions of this Vision. Source: (White House, 2020)

\section{Anti-Terrorism Apparatus}

The State of Palestine's security criteria has to be acceptable to the State of Israel; not (less) stringent than the metrics used by either Jordan or Egypt (whichever is stricter) with respect shall be obeyed. The State of Palestine's counterterrorism system must encompass all elements of counterterrorism.( White House,2020)

\section{Border Regime}

The State of Israel will be responsible for security at all international crossings into the State of Palestine. The Jerusalem Post, (2020) has cited that the State of Israel will continue to maintain control over the airspace and the electromagnetic spectrum, the Israeli Navy will have the right to block prohibited weapons and weapon-making materials from entering the State of Palestine.

The State of Palestine will not have the right to forge intelligence or security agreements with any state or organization that adversely affect the State of Israel's security, as determined by the State of Israel.

\section{Status of Jerusalem and Holy sites}

The plan gives the entirety of "undivided Jerusalem" to Israel, recognizing it as Israel's capital. The Palestinians would get neighborhoods in the outer portions of eastern Jerusalem beyond the Israeli West Bank barrier, including Kafr 'Aqab, Shu'fat camp (described as "the eastern part of Shuafat") and Abu Dis. Martin Indyk described the Palestinian portion as "only a sliver of East Jerusalem"' (Trump Peace Plan, 2017)

The plan puts the Temple Mount, including Al-Aqsa mosque, under Israeli sovereignty. It calls for the status quo to be maintained. According to Lee, M (2019) has cited that the plan rejects Palestinian claims to Haram alSharif, instead keeping it under Jordanian custodianship. The plan gives Israel the task of safeguarding the Holy Sites and guaranteeing freedom of worship.

\section{Borders and territory}

The plan recognizes Palestinian rights to roughly $70 \%$ of the West Bank. The plan called for land swaps, but dismissed the idea of "1-to-1 land swaps", arguing Palestinians would not receive 100 percent of pre-1967 territory, but provided for territory that would be "reasonably comparable" to pre-1967 territory. Betaman, T (2020) has discussed that in exchange for Israel annexing parts of the West Bank, the Palestinians would parts of the Negev Desert; these parts in the Negev would be disconnected from much of the Palestinian state. The Trump plan gives Palestinians less territory than previous proposals.

The plan recognizes an Israeli right to the entire Jordan Valley. Israel regards the valley as militarily strategic. Palestinians regard the valley as important for agriculture. The valley also allows Palestinians access to the River Jordan, which irrigates 80,000 hectares of agricultural land in the West Bank; giving Israel the valley would allow it to divert that water for its own use.(White House,2020)

Within the West Bank, approximately $97 \%$ of Palestinians would be incorporated into contiguous Palestinian territory and $97 \%$ of Israelis into contiguous Israeli territory. Gaza to be part of State of Palestine only after achievement of the "Gaza Criteria" The State of Israel will implement its obligations only: Hamas, PIJ, and all other militias and terror organizations in Gaza are disarmed. Gaza is fully demilitarized. Hamas, at large (not only Gaza), must commit to the path of peace with the State of Israel by adopting the Quartet principles, which include unambiguously and explicitly recognizing the State of Israel, committing to nonviolence, and accepting previous agreements and obligations between the parties, including the disarming of all terrorist groups.(BBC News, 2020)

\section{Status of prisoners}

Israel will release of Palestinian prisoners and administrative detainees held in Israeli prisons. All prisoners who are released will become citizens of the State of Palestine. The US proposal for Middle East, (2017) has cited that Israel will not release:

1. Convicted of "murder" or "attempted murder".

2. Convicted of conspiracy to commit murder ("terrorist").

3. Any 1 and 2, which hold Israeli citizenship. 


\section{History of President Trump Peace Plan}

Baker, P (2017) has linked the development of the peace plan strategies of President Trump began in November 2017, led by Kushner, Chief Negotiator Jason Greenblatt, Deputy National Security Adviser Dina Powell, and Ambassador David Friedman. Kushner, a real estate developer married to Trump's daughter Ivanka, had no prior experience of Middle East diplomacy, asked the parties not to talk about history, and never really discussed his plan with the Palestinians.

Friedman had close ties to the Israeli settlers in the occupied West Bank, compared Jewish American critics of Israel to collaborators with Nazism and was skeptical about the idea that Palestinians should have a state.( Mcgreal, 2020) On Greenblatt's resignation, he was replaced by Avi Berkowitz, a young lawyer who worked for Kushner's companies, who like Kushner, was raised as an orthodox Jew with deep ties to Israel.

In December 2017, Trump recognized Jerusalem as Israel's capital .A key member of Trump's team, the Arabist Dina Powell, quit in protest two days after the announcement.(Amir,2017) The move was condemned by Arab countries, and Palestinians broke off contacts with the Trump administration. Jason Greenblatt, who played an important role in the decision, and also in Trump's acceptance of Israeli sovereignty over the Golan Heights, was thereafter shunned by the Palestinian authority until his resignation two years later in September 2019. In their view, he acted as Israel's spokesman, a country he would never criticize, while, in the following two years, he would frequently lambast the Palestinian side on his Twitter account. Raphael, A. (2019) has cited the nature of Trump reacted by ending both bilateral aid for Palestinians and contributions for UNRWA, citing the PA's refusal to take part in the administration's peace initiative. The UN has demonstrated how the United States also shut down the Palestinian diplomatic office in Washington. (New York Times, 2019)

At the U.S.-led "Peace to Prosperity" conference in Manama, Bahrain, held in late June 2019, at which the economic plan was to be unveiled, Palestinian leaders boycotted and condemned the conference. The Palestine Liberation Organization (PLO) accused the US of trying to sell a "mirage of economic prosperity" that would in reality "only perpetuate the Palestinians' captivity." Hamas leader Ismail Haniyeh criticized the Arab leaders attending the conference, saying "The (Palestinian) people, who have been fighting for one hundred years, did not commission anyone to concede or to bargain. Jerusalem is ours, the land is ours, and everything is ours." Reuters (2019) In December 2017, Trump recognized Jerusalem as Israel's capital.

In November 2019, the US abandoned its four-decades-old position that Jewish settlements in the West Bank were inconsistent with international law.

Kushner said that the peace proposal will not include the phrase "two-state solution", saying "If you say 'twostate', it means one thing to the Israelis; it means one thing to the Palestinians. We said, 'You know, let's just not say it. Let's just say, let's work on the details of what this means."' The BBC News (2020) has lighted a top-ranking Saudi diplomat stated that the plan includes a "clear path leading to complete Palestinian independence". Greenblatt (2019) said that the plan "will include a resolution to all of the core issues, including the refugee issue, and will also focus on Israel's security concerns", and that the plan does not call for a confederation model or for a transfer of land from Egypt's Sinai Peninsula to the Palestinians.

Kushner has likened the plan to the Marshall Plan to rebuild Western European economies after World War II. (Reuters, 2019)

President Trump peace plan is a proposal by the Trump administration bearing the stated intention of resolving the Israeli-Palestinian conflict. Donald Trump formally unveiled the plan in a White House press conference alongside Israeli Prime Minister Benjamin Netanyahu on 28 January 2020; Palestinian representatives were not invited(Deutsthe, 2020)

"Together we can bring about a new dawn in the Middle East," said Trump, who also called it "the toughest deal ever to make." He thanked the governments of Oman, Bahrain and the United Arab Emirates for their assistance in the peace process.

Netanyahu called it a "historic day" on a par with May 14, 1948, when US President Harry Truman became the first international leader to recognize the state of Israel.

"Mr. President, I believe that down the decades, and maybe even down the centuries, we will remember January 28, 2020," Netanyahu continued, saying the plan was "a realistic plan for durable peace."

The plan was authored by a team led by Trump's son-in-law, Senior Advisor to the President of the United States Jared Kushner. BBC News (2020) has highlighted the various news organizations and scholars have referred to the plan as the "deal of the century", although there is no record of U.S. President Donald Trump or the Trump administration using the name. Both the West Bank settlers' Yesha Counci and the Palestinian leadership rejected the plan: the former because it envisaged a Palestinian state, the latter arguing it is too biased in favor of Israel. The plan is divided into two parts, an economic portion and a political portion. On 22 June 2019, the Trump administration released the economic portion of the plan, titled "Peace to Prosperity". The political portion was released in late January 2020.

During the press conference announcing the plan, Netanyahu announced that the Israeli government would 
immediately annex the Jordan Valley and West Bank settlements, and US Ambassador to Israel David M. Friedman confirmed that the Trump administration had given permission for an immediate annexation, stating that "Israel does not have to wait at all" and "we will recognize it." Opponents of the Trump Peace Plan - including all the leading Democratic presidential candidates have denounced it as a "smokescreen" for this annexation. Proposed benefits to the Palestinians from the plan are contingent on a list of conditions which have been denounced by opponents of the plan as "impossible" or "fantastic". An editorial of the Los Angeles Times stated that the plan had arrive 'dead in the water'(Los Angeles Times, 2020)

\section{Matters Arising for Trump Peace Strategy}

Since taking office, U.S. President Donald Trump has said he wants to strike a peace deal between Israelis and Palestinians. Details about his on-again, off-again peace plan are sparse. Washington recently unveiled the economic component of its vision, which will be discussed at the Peace to Prosperity workshop in Bahrain this week. But neither the Israeli government nor the Palestine Liberation Organization (PLO) will be there.

What do the countries involved think of the latest attempt to resolve one of the world's thorniest diplomatic challenges?

\section{Palestine}

If there is one thing that the Palestinian leadership and the people agree on, it is that the unreleased U.S. peace plan should be rejected on sight and that Palestinians should not participate in the economic workshop the United States is organizing in Bahrain. If the issues of Jerusalem, refugee return, and sovereignty are off the table, Palestinians say that there can be no peace and that the United States has disqualified itself as a neutral broker. They point out how Washington's economic vision talks about supporting Palestinians" "ambitions" rather than their national aspirations. What's more, it fails to address the root cause of Palestine's economic woes - the persistence of Israel's military occupation. They do not believe that the United States wants to support Palestinian development, given that Washington has ended all economic assistance to Palestine. If U.S. and Israeli sanctions continue, the Palestinian Authority will be unable to pay its employees, including its security forces, and the government may collapse by July or August 2019.

Though Palestinian leaders say they are boycotting the workshop, the U.S. administration actually chose to bypass official Palestinian representatives in favor of the private sector. A few may attend, but the vast majority of Palestinian business leaders and investors, claiming to account for four-fifths of the occupied Palestinian territories' gross domestic product, won't go to Bahrain. The way to unlock Palestine's economic potential, they say, is not by way of dollars or riyals, but instead by ending the occupation and allowing people and goods to move freely (Steinbush, 2019)

\section{Israel}

The biggest winner in the new peace plan would be Israel and Prime Minister Benjamin Netanyahu. The Trump administration has gone far beyond previous U.S. administrations in its overt support for Israel. This is clear from its peace team, which includes Jared Kushner, a close family friend of Netanyahu, and Ambassador David Friedman, a longtime donor to Israeli settlements. But Netanyahu faces a political crisis at home. On May 30, 2019, he failed to form a government. This triggered another round of elections to be held September 17, 2019, two weeks before his pre-indictment hearings on corruption charges. The Trump team is unlikely to release the full plan before those elections.

If the plan comes out earlier and is rejected by the Palestinians that would accelerate Netanyahu's plan to annex some or all of the Israeli settlements in the West Bank, with the Trump administration's blessing. Trump has already given Netanyahu more than he could have expected-moving the U.S. embassy to Jerusalem, recognizing the Golan Heights as Israeli territory, cutting all U.S. assistance to Palestinians, and dismantling the PLO office in Washington.

But while the Israeli political machine has been steadily chipping away at the prospects for peace, the Israeli people are not yet fully on board. Nearly twice as many Israelis support a two-state solution compared to those who support a one-state solution. Grassroots groups are actively committed to a peaceful resolution to the conflict. On June 5, the U.S. Congress announced its intention to fund those coexistence efforts (Reuters, 2019)

\section{Saudi Arabia}

Despite hints of a Saudi opening toward Israel from Crown Prince Mohammed Bin Salman in 2018, Riyadh's position toward Palestine has not radically changed. King Salman Bin Abdulaziz, has increased Saudi financial assistance for the Palestinians, and he constantly reiterates the country's unwavering support. The crown prince reportedly stated the same position in February 2019.

For religious reasons, Muslim nations would condemn any Saudi embrace of a peace plan that recognizes Jerusalem as the capital of Israel. Some would use such a development to challenge the kingdom's status in the 
Muslim world. To accept Trump's peace plan would also add more fuel to the fire among Saudi circles angered by the social and political changes in the Kingdom.

Yet Riyadh can't afford to reject Washington's proposal outright. The king will likely keep doubling down on support to the Palestinians, while avoiding actions that jeopardize relations with the United States or undermine growing security cooperation with Israel. Israel is the key to continued U.S. support for Saudi Arabia and for tougher policies against Iran (Arab, News, 2019)

By joining U.S. diplomatic efforts and attending the Bahrain workshop with several other countries, Saudi Arabia will be able to mask its interactions with Israel in a haze of expanding Arab-Israeli ties and pass the burden of rejecting the peace plan to the Palestinian Authority. The king has said that he will follow the Palestinians' lead, "accepting what they would accept and rejecting what they would reject." (Deutsche Welle, 2020)

\section{Egypt}

Egypt is expected to play an important part in the Trump plan. Reportedly, it would be asked to host an economic zone for Palestinians in northern Sinai, next to Gaza. While that might seem like a harmless idea, and one that could bring generous aid from the Gulf, it would be difficult for Cairo to accept.

Magrib, J (2020) has cited that first, providing greater access from Gaza is a security nightmare. Egypt has an ongoing battle with extremist groups in northern Sinai and would not want them resupplied from Gaza. Second, Cairo has long resisted taking on more responsibility for the welfare of Palestinians in Gaza, where repeated clashes between Hamas and Israel tend to destroy whatever is achieved. Third, Egyptian soldiers died to regain Sinai from Israel, and Egyptian citizens are highly sensitive to any suggestion that their country might give away part of the territory. Sisi's surrender of two small islands to Saudi Arabia in 2016 caused public protests and anger even within elite circles.

Sisi is eager to preserve his warm relationship with Trump and will play along as best he can with peace efforts including by taking part in the Bahrain meeting. But he might well hope that Trump's touted "deal of the century" withers on the vine. As soon as the Sinai aspect of the deal was leaked in early June, Sisi quickly reassured an Egyptian audience that "nobody can do anything that you do not want. Can you imagine that I would ever let go of our rights? Why would I do that?"

\section{Jordan}

The economic part of the U.S. peace plan appears to mistakenly assume that Palestinians' political aspirations can be traded for financial incentives and that the two-state solution may be abandoned. That would be detrimental to Jordan.

If there is no Palestinian state in the West Bank and Gaza, and if the Israelis do not want areas under their control to have a Palestinian majority, Jordan fears the solution might come at its expense. Either Israel could annex the parts of the West Bank it wants and expect Jordan to deal with the rest, or Israel could force Palestinians to immigrate over time-mostly to Jordan.

Faced with such an existential threat, Jordan is in no position to accept the deal, despite pressure from the United States to attend the Bahrain workshop. In essence, Amman faces two bad options. It can join the conference, thereby diluting its own position. Or Jordan can decline to go and risk angering the United States, an ally it is heavily dependent on politically and economically (Biden, 2020)

Both options are possible, although any Jordanian participation is likely to be low level and would be used to highlight the negative effects such a deal would have on the country. In the case of any U.S. anger, Jordan will probably solicit the help of an understanding Congress, as well as several departments within the U.S. administration, most notably the Pentagon and the CIA.

\section{Morocco}

Although 600,000 Israelis originate from Morocco, Rabat tends to keep its business and security links to Israel quiet. The king has a largely ceremonial role as the chair of the Al Quds Committee, which seeks to maintain Arab claims to Jerusalem.

Historically, Morocco has been a minor player, but it is becoming more notable for two reasons: U.S.Morocco relations and the Western Sahara conflict. Officially, Morocco supports the two-state solution. But establishing formal relations with Israel and supporting the new U.S. peace plan would let Rabat gain favor with Washington. The leadership might be tempted to endorse the plan if given the right offer: international recognition of its sovereignty claims over the Western Sahara. Given Kushner's recent trip to Morocco, Rabat may rightly believe that the Trump administration is willing to accept a quid pro quo for public Arab support for the peace plan.

In agreeing to attend the workshop, Morocco is likely balancing the benefits of closer ties with the Trump administration against the domestic political fallout of supporting a plan that is likely to harm Palestinian interests. The Arab-Israeli conflict and Palestinian rights have consistently been an important popular issue in Morocco, but 
the country's leadership may bet that younger generations will not be as galvanized by the Palestinian cause if they are offered the right incentives.

\section{Europe}

Not long ago, Europe aspired to play a pivotal diplomatic role in the Middle East. After the 2009 Lisbon Treaty, the European Union's (EU) then foreign policy chief Cathy Ashton negotiated extensively (though secretly) in the region. The first official visit of her successor, Federica Mogherini, was to Israel and the Palestinian territories. She called for the creation of a Palestinian state within five years and announced that the EU intended to play a more influential role in the Middle East. She also named one of the EU's most skilled diplomats-Fernando Gentilini, who had negotiated the Serbia-Kosovo agreement - as EU special envoy to the Middle East. (Street, 2019)

Yet today, the EU's role in the Middle East is at an all-time low. Its influence has faded since the United States withdrew unilaterally from the Iran deal, which had been a major joint accomplishment. The EU's inability to keep the Iran deal alive, the U.S. decision to move its embassy to Jerusalem, and Kushner's plan to stop short of calling for a Palestinian state all show that the EU's sway in the Middle East is now minimal.

\section{United States}

The prospect of new Israeli elections in September has disrupted the timing of Trump's Middle East peace plan. The U.S. administration had already announced the June workshop in Bahrain when this news broke, and Washington is intent on following through. But it is hard to see how diplomacy can progress further. Launching a peace plan during an Israeli election campaign makes no sense. And once the new Israeli government takes office, the U.S. election campaign will be well under way, leaving the Trump administration little room to maneuver.

The looming Israeli elections may have given the U.S. administration a face-saving exit ramp. Palestinians are deeply opposed to Trump's so-called "deal of the century." Whether or not Washington opts to shelve the plan after the Bahrain gathering, the administration could still face a major decision on how to respond to Israeli annexation in the West Bank. Such a step by Israel will certainly provoke a harsh Palestinian reaction and would have significant implications for the future.

\section{Consequences of President Trump Peace Deal in Middle East}

In a much-anticipated speech from the White House, Mr. Trump argued that it was "the right thing to do" to acknowledge the reality that Jerusalem is the seat of Israel's government. Decades of avoiding that fact, he said, has done little to resolve the protracted feud between Israelis and Palestinians.

"It would be folly to assume that repeating the exact same formula would now produce a different or better result," Mr. Trump declared. Recognizing Jerusalem as Israel's capital, he said, is "a long overdue step to advance the peace process."

Mr. Trump said that the United States still wanted a negotiated peace agreement - and "would support a two-state solution if agreed to by both sides" — and that he was not seeking to dictate the boundaries of Israeli sovereignty in the fiercely contested Holy City.

"There will, of course, be disagreement and dissent regarding this announcement," the president said. He appealed for "calm, for moderation, and for the voices of tolerance to prevail over the purveyors of hate."

Mr. Trump's recognition of Jerusalem isolates the United States on one of the world's most sensitive diplomatic issues. It drew a storm of criticism from Arab and European leaders, including some of America's closest allies.

Many said that Mr. Trump's move was destabilizing, that it risked setting off violence and that it would make achieving peace even more difficult. It also threw into doubt his ability to maintain the United States' longstanding role as a mediator of the Israeli-Palestinian conflict.

Mr. Trump's break with policy and international consensus included setting into motion a plan to move the United States Embassy from Tel Aviv to Jerusalem. Although that will not happen right away, Palestinians saw it as a deep affront.

The Palestinian president, Mahmoud Abbas, a veteran of the peace process, said bitterly that the United States had effectively scrapped it. Saeb Erekat, the chief Palestinian negotiator, called for the abandonment of a two-state solution altogether.

Among Israelis, however, Mr. Trump's announcement drew praise, not only from Prime Minister Benjamin Netanyahu's right-wing government but also from liberal opposition leaders. "The Jewish people and the Jewish state will be forever grateful," Mr. Netanyahu said in a video, calling Mr. Trump's decision "courageous and just" and "an important step towards peace."

Yair Lapid, the leader of Yesh Atid, a center-left opposition party, said: "Policies should not be dictated by threats and intimidation. If violence is the only argument against moving the embassy to Jerusalem, then it only proves it is the right thing to do." 
Naftali Bennett, the education minister and leader of the right-wing Jewish Home party, said American recognition of Jerusalem as Israel's capital "shows that Israel's strategic patience has paid off."

"We have been told again and again that if we want more acceptances, we have to cut off parts of Israel and hand them over to our enemies," he said. "What we are learning is the contrary: The world respects strong countries who believe in themselves and looks down on countries willing to give up their homeland."

Yet Israelis also braced for violence, as some Palestinian leaders urged a third intifada, or armed uprising. Fatah, Hamas and other Palestinian factions called a general strike from Thursday $6^{\text {th }}$ February, 2020 urging residents of the West Bank and Gaza to join marches in every city, and officials said the Palestinian schools would be closed. Hamas, an Islamic militant group, said Mr. Trump's decision would “open the gates of hell," and Islamic Jihad called it a "declaration of war."

By late Wednesday night, there were only scattered, unconfirmed reports of gunfire and clashes with security forces in several West Bank cities. But the United States Consulate General in Jerusalem barred American government employees and their families from visiting Jerusalem's Old City and the West Bank, including Bethlehem, already decorated for Christmas. Government workers were permitted to conduct essential travel only. American citizens were advised to avoid crowds.

In Jordan, the United States Embassy said it had suspended routine public services, limited the public movements of employees and their families and instructed them not to send their children to school on Thursday.

But even as Arab and Muslim leaders across the Middle East condemned Mr. Trump's announcement, doubts were raised about the stamina of the anger. The Palestinian issue, long a binding force in Arab politics, has slipped in importance in recent years, overshadowed by other conflicts. Still, the American decision risked a backlash with unpredictable consequences.

Palestinians across the political spectrum said Mr. Trump's decision was so biased toward Israel that he had irrevocably harmed his administration's ability to be seen as a fair broker.

Analysts noted that Mr. Trump had said nothing about Palestinian aspirations to make East Jerusalem the capital of a state side-by-side with Israel.

Mr. Trump made no distinction between the western portions of the city and East Jerusalem. The Old City landmarks he invoked - the Western Wall holy to Jews, the stations of the cross sacred to Christians, and AlAqsa mosque, which is cherished by Muslims - are all east of the 1967 line, in what the rest of the world still considers occupied territory, said Nathan Thrall, an expert on the Israeli-Palestinian conflict at the International Crisis Group.

Mr. Trump's formulation that the United States "would support a two-state solution if agreed to by both sides," too, amounted to a rolling back of United States policy flatly supporting a two-state solution, said Daniel Kurtzer, a Princeton professor and former ambassador to Israel under President George W. Bush.

"There's really not much for Abbas to hang onto if he wanted to stay in the game with the U.S.," Mr. Kurtzer said.

Mr. Trump's decision was driven by a campaign pledge. He appealed to evangelicals and ardently pro-Israel American Jews when running for president in 2016 by vowing to move the embassy. Advisers said he was determined to make good on his word.

But the president still plans to sign a national security waiver to keep the embassy in Tel Aviv for an additional six months, even as the relocation plan moves ahead.

White House officials argued that Mr. Trump's decision would bolster his credibility as a peacemaker by showing he can be trusted to deliver on promises. They also argued that by taking the contentious issue of Jerusalem off the table, Mr. Trump had removed a recurring source of ambiguity.

Those arguments were rejected by Mr. Abbas, who said in a televised speech Wednesday night that Mr. Trump's actions "constitute a deliberate undermining of all peace efforts" and amounted to a "withdrawal" from America's role.

The decisions on the embassy and recognition of Jerusalem "also reward Israel for denying agreements and defying international resolutions, and encourage Israel to pursue the policy of occupation, settlement, apartheid and ethnic cleansing," Mr. Abbas said, speaking in Arabic that was translated by Wafa, the Palestinian news agency.

Yet the Palestinians, weak and divided, did not appear to have many good options or any clear, ready response.

Some raised the idea of severing security cooperation with Israel, but that cooperation also helps preserve Mr. Abbas's authority. And breaking more forcefully with the United States could jeopardize the vast sums of aid the Palestinian Authority receives from Washington.

Mr. Abbas said he would focus on reconciliation efforts with Hamas to face the new challenge. But the American declaration could actually hurt those efforts.

"This development will push Hamas to become more hard-line," said

Ghassan Khatib, a Palestinian political scientist at Birzeit University in the

West Bank. "Abbas will not change his political line, so the gap will grow." 
Diana Buttu, a Palestinian lawyer-activist and former aide to Mr. Abbas, said the peace process had failed him. "He has to switch tactics," she said, pointing to international measures like the boycott-divestment-sanctions campaign and pressing charges against Israelis in the International Criminal Court.

"Doing nothing is no longer an option," she said.

Mr. Thrall, the analyst, said the two-state strategy had been losing credibility among Palestinians for some time, particularly among the young. And Mr. Trump's actions, he said, would push more Palestinians toward what he called "a rights-based struggle for equality," and "a one-state, South African model for Palestinians."

"Nothing better symbolizes for Palestinians the idiocy of the strategy that their leaders have been pursuing and the absolute fruitlessness of it than what just happened at the White House today," he said.

Israel's standing in the world generally suffers when there is no prospect of peace negotiations. But Israelis on both the right and left dismissed the notion that Mr. Trump's declaration was a death knell.

The right described it as more of a reality check. "It doesn't matter what Trump says," said Efraim Inbar, president of the Jerusalem Institute for Strategic Studies, a conservative think tank. "It matters if the Palestinians are ready to compromise on this issue or not."

Still, Mr. Netanyahu could now face a new set of political problems from Mr. Trump's announcement, including increased pressure from key allies to press Israel's advantage over the Palestinians.

Already, there is a push to redraw the boundaries of Jerusalem to eject much of its Arab population and add tens of thousands of residents to Israeli settlements.

"The problem he's going to have is, will he now be able to control the appetites of those in his coalition who want to do even more?" Mr. Kurtzer said.

Others warned that Israel might have to pay a price down the road if Mr. Trump — assuming he is serious about peacemaking — offers a concession to the Palestinians.

"The next time Trump wants something from Israel," said Nachman Shai, a Labor Party member of the Knesset, "I'd like to see who will say no."

\section{Bloc of Muslim Nations Warns Trump Israel-Palestine Plan 'Destroys the Foundations of Peace'}

The Organization of Islamic Cooperation emphasized that "peace and security in the Middle East region, as a strategic option, will only be achieved with the end of the Israeli occupation.

Organization of Islamic Cooperation (OIC) Secretary-General Yusuf bin Ahmed Al-Othaimeen (L) and Foreign Minister of the Palestine Riyad al-Maliki attend the OIC's emergency open-ended executive committee ministerial meeting in Jeddah, Saudi Arabia on Feb. 3, 2020. (Los Angeles Times, 2020)

Joining global critics of a plan that President Donald Trump unveiled last week to address the decades-long Israel-Palestine conflict, the Organization of Islamic Cooperation on Monday rejected the "biased" proposal and urged members states not to cooperate with U.S. efforts to enforce it.

At a meeting in Jeddah, Saudi Arabia, the OIC executive committee adopted a resolution which decried Trump's so-called "Deal of the Century," reaffirmed support for the Palestinian people and the Palestine Liberation Organization headed by Mahmoud Abbas, and emphasized that "peace and security in the Middle East region, as a strategic option, will only be achieved with the end of the Israeli occupation."

The 57-member body of Muslim-majority countries declared that Trump's plan "lacks the minimum requirements of justice and destroys the foundations of peace, including the agreed legal and international terms of reference for a peaceful solution and the need to respect and recognize the inalienable rights of the Palestinian people, including the right to national independence and of Palestine refugees to return."

The resolution expressed "regret at the biased approach of the 'plan' that fully adopts the Israeli narrative and endorses the annexation of vast areas of the occupied land of the State of Palestine, under the pretext of security for Israel, the illegal occupying power, in flagrant violation of the principles of international law, the inadmissibility of the acquisition of territory by force, the United Nations Charter, and relevant international resolutions."

According to the resolution, Israel is "responsible for the deterioration of the situation on the ground because of its denial of relevant agreements, its defiance of international legitimacy and the continuation of the policies of colonization, annexation, settlement expansion, discrimination and ethnic cleansing, which have been perpetrated against the Palestinian people in the occupied Palestinian territory, including East Jerusalem."

Along with warning Israel against making any further moves "to consolidate its colonial occupation in the territory of the State of Palestine," the OIC called on the international community to reject and confront "any action or proposal that is inconsistent with international law and relevant United Nations resolutions."

The resolution came just two days after the Arab League also rejected Trump's proposal, concluding that "it does not meet the minimum rights and aspirations of Palestinian people," and vowed to not cooperate with the U.S. efforts to implement the plan. 
Abbas, the Palestinian Authority president, announced at the Arab League meeting that in the wake of the plan's unveiling, "We've informed the Israeli side ... that there will be no relations at all with them and the United States including security ties." The Palestinian leader has declined to communicate with Trump by phone or letter.

Other critics of the proposal - which Trump introduced at the White House week with Israeli Prime Minister Benjamin Netanyahu by his side-have denounced it as an "annexation plan." Last week, Rep. Ilhan Omar (DMinn.) called it "shameful and disingenuous" while Sen. Bernie Sanders (I-Vt.), a 2020 White House hopeful, warned that the plan "will only perpetuate the conflict."

The OIC resolution also came as Agence-France Presse reported that the United States requested a closeddoor United Nations Security Council meeting on $6^{\text {th }}$ February, Thursday 2020 for a presentation by Jared Kushner, Trump's son-in-law and senior adviser, who oversaw the development of the administration's plan.

That meeting would occur just days before Abbas is set to arrive at the U.N. on Feb. 11 "to express opposition to the U.S. plan and to demand adherence to international law," AFP noted. "On the occasion of Abbas' visit, the Palestinians have indicated they plan to submit a draft resolution to the Security Council, through Tunisia, a nonpermanent member of the council."

\section{Conclusion}

Apart from the religious issue, the land issue also aggravated the conflict between Israel and Palestine. The two nations have been for a long time been involved in conflict over land issues. Israeli settlement in the western part has been the main land issue. The occupation of the west bank and Gaza strip has been the main focus. Palestine wanted Israel to return all the land that it conquered in the 1967 war. Israel refused to do so and instead continue to develop settlements throughout the peace process. Refugees that were pushed away from their homes in 1948 when Israel was created and others who were affected in 1967 has been an issue in the conflict. Palestinians want these refuges to be resettled at their original homes in Israel. Israel has opposed the resettlement of these refuges claiming that it will result to Arab Palestinian majority and would finish Israel as a state for Jews

The Palestinian state has also been an issue of concern. The Palestinian liberation movement wanted a two state solution which Israel is against. Mainstream Palestinian wants a state to be created in the west bank and Gaza. Israelis are opposed to this because they think it will act as a breeding ground for terror associations. Israel repression in response to Palestinian violence became a major issue of concern in the conflict. It did this first by reducing the entrance of Palestine at the border. This brought down Palestinians standards of living and was humiliated at the check points. Following terror attacks, Israeli forces opened fire quickly sometimes killing innocent civilians.

The conflict between Israel and Palestine has had some serious implications. Monetary implications have been great for the two countries. Much money and funds have been used to purchase arms and equipment used in the war. Millions of dollars have lost; the economic growth of the two countries was unstable. Heavy budgeting on the war has had a negative influence on the economies of the two countries.

\section{Recommendations}

The paper has the following recommendations for peace to be sustained in the Middle East:

i. Official and unofficial actors from the international community should seek to create forums and time to promote brainstorming and exchange of ideas that involve Israeli and Palestinian communities with regard to peace and ways of achieving it. This not only raises the awareness of each other's grievances but also formation of equal and strong networks where ideas are voiced without consequence.

ii. Communities and leaders from both two groups must be ready for and be encouraged to make compromise in order to achieve peace.

iii. Arab states are supposed to help Palestinians in this process. Americans and Europeans are supposed to work through political options ahead of negotiations. This support would enable Palestinian leadership to pick up on the positive Israel gestures and proposals as well as pressure Israeli leadership to respect international momentum towards peace.

iv. Lastly there is need for leaders and communities to face the hard truths of the conflict. The basic issues such as the borders, security, refugee return and settlement are not going away but must be faced in peace efforts. Efforts must address the security of Israel and the finality of the agreement, making clear to Palestinians Arabs for ensuring peace.

\section{References}

Arab News , June 23, 2019. Retrieved June 24, 2019

"At UN, Abbas (2019) threatens to nix agreements with Israel if West Bank land annexed". The Times of Israel September 26, 2019.

AFP and TOI staff "A look at some of the details of the economic aspect of the Trump peace plan" The Times of 
Israel, Retrieved June 24, 2019

Amir Tibon,'Amid Jerusalem Crisis, Top Middle East Advisor Dina Powell Quits White House,' Haaretz 9 December 2017

Ahren, Raphael. "Greenblatt tells ToI: US won't propose Israel-Jordan-Palestinian confederation". The Times of Israel Retrieved June 24, 2019

Baker, P (2017). "Trump Team Begins Drafting Middle East Peace Plan". The New York Times. Retrieved June 23,2019

Cortellessa, E (2019) . "White House finally unveils 'Peace to Prosperity' economic plan for Palestinians". The Times of Israel, Retrieved June 24, 2019

"Exclusive: White House's Kushner unveils economic portion of Middle..." Reuters. June 23, 2019. Retrieved June 23, 2019.

"How Trump's Peace Plan Will Change the Middle East". Time.

"What will Palestinians lose if Israel annexes Jordan Valley?". Al Jazeera. January 28, 2020.

"Jared Kushner Unveils Economic Portion Of Middle East Peace Plan". HuffPost. June 22, 2019. Retrieved June 24, 2019

Lee, M (2020). "Trump peace plan delights Israelis, enrages Palestinians". , . It sides with Israel on key contentious issues that have bedeviled past peace efforts, including borders and the status of Jerusalem and Jewish settlements, and attaches nearly impossible conditions for granting the Palestinians their hoped-for state.

McGreal, C ( 2020). "'Don't talk about history': how Jared Kushner crafted his Middle East 'peace' plan". The Guardian. ISSN 0261-3077. Retrieved January 29, 2020

Magid, J ( 2020). "'Settler leaders call on PM to oppose Trump plan, even at the cost of annexation"'Trump reveals Israeli-Palestinian peace plan". Deutsche Welle. January 28, 2020.

Magid, Jacob. "Borders, security, Jerusalem, settlements, refugees: Key elements of Trump plan". www.timesofisrael.com. Retrieved January 29, 2020.

Nahmias, O ( 2019). "White House releases detailed economic plan for Palestinian people". The Jerusalem Post. Retrieved June 24, 2019

Relman, E ( 2017). "Jared Kushner's 28-year-old protégé is his right-hand man in the White House". Business Insider.

Raphael, A (2019) Trump peace plan architect Jason Greenblatt to quit administration The Times of Israel 5 December 2019

Street, J (2019) IT'S NOT A PEACE PLAN, IT'S AN ANNEXATION SMOKESCREEN, "If there was ever any doubt that the Trump-Netanyahu "peace plan" was anything other than a smokescreen for annexation, it was disabused just moments after the plan's glitzy White House announcement."

Steinbuch, Y (2019). "Jared Kushner says Mideast peace plan won't say 'two states"'. New York Post. Retrieved June 23, 2019.

"Saudi official says 'Deal of Century' leads to full Palestinian statehood - Israel News - Jerusalem Post". The Jerusalem Post. Retrieved June 23, 2019

PR campaign, not a peace plan: (2018) "But while the promise of Palestinian statehood is contingent on fantastic conditions, the plan sets no conditions for allowing Israel to annex the Jordan Valley and all Israeli settlements in the West Bank." "Editorial: Trump's long-awaited Middle East peace plan is finally here. And it's dead in the water". Los Angeles Times. January 28, 2020.

"Trump releases long-awaited Middle-East peace plan". BBC News. January 28, 2020.

"No, Trump doesn't call Mideast plan 'deal of the century"'.

The Times of Israel. "Democratic candidates censure Trump peace plan, warn against annexation". The Times of Israel. January 28, 2020. Biden: "This is a political stunt that could spark unilateral moves to annex territory; Warren: "Trump's 'peace plan' is a rubber stamp for annexation"; Buttigieg: "Peace requires both parties at the table. Not a political green light to the leader of one for unilateral annexation.

"Trump Outlines Mideast Peace Plan That Strongly Favors Israel". New York Times , 2019.

"Trump peace plan: Palestinian state, Israeli control of settlements". The Jerusalem Post | JPost.com. Retrieved January 28, 2020.

"Trump's Israel-Palestine peace plan, explained". Vox (website).

"TRUMP UNVEILS THE "GIVEAWAY OF THE CENTURY" ON MIDDLE EAST PEACE". New Yorker.

"Trump releases long-awaited Mid-East peace plan". BBC News. January 28, 2020. Retrieved January 28,2020

"Trump Called His Middle East Peace Plan a 'Win Win.' Palestinians Disagree". Time. 48 Bateman, Tom (January 28, 2020). "Smiles and sorrow for Trump's 'realistic' peace plan" - via www.bbc.com.

"Trump proposes Palestinian state with capital in East Jerusalem". Reuters. January 28, 2020. Retrieved January 28,2020

"U.S. ends aid to United Nations agency supporting Palestinian refugees". The Washington Post. August 31, 2018. Retrieved September 2, 2018. 
"US opens debate on Mideast economic plan shunned by Palestinians". Reuters. June 26, 2019.

"U.S. Mideast plan will not include land transfer from Egypt's Sinai: envoy". Reuters. April 19, 2019. Retrieved June 24, 2019.

"US Ambassador to Israel: Before Israel annex, a committee is in order". Jerusalem Post. January 29, 2020. Retrieved January 29, 2020.

"President Donald J. Trump's Vision for Peace, Prosperity, and a Brighter Future for Israel and the Palestinian People". The White House.

Peace plan, page 34

"Palestinians reject Trump's Middle East peace plan". BBC News. January 29, 2020.

WhiteHouse 2020, p. 42

WhiteHouse 2020, p. 7

WhiteHouse 2020, p. 8

WhiteHouse 2020, p. 43

"White House unveils economic portion of Middle East peace plan". Jewish Telegraphic Agency. June 22, 2019. Retrieved June 24, 2019.

WhiteHouse 2020, p. 22

WhiteHouse 2020, p. 51

WhiteHouse 2020, p. 53

WhiteHouse 2020, p. 25

WhiteHouse 2020, p. 26

WhiteHouse 2020, p. 30. 